\title{
Theosis in die Oosters-Ortodokse en Westers-Protestantse teologiese debat
}

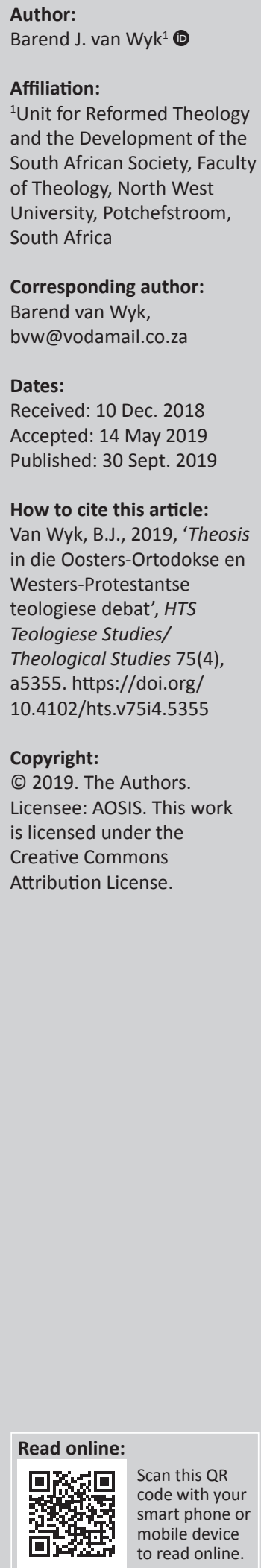

Theosis in the Eastern-Orthodox and Western-Protestant theological debate: All major religions agree on one theme, namely they strive to provide an answer regarding the relation with their God. A good relation to God is the way of salvation, because the question about God is an acknowledgement that a human being needs to be in union with God. Some questions and answers are only possible in the relation between God and humankind. The well-known saying from the letter to the Romans (1:17), is typical of such a relation formulated in the Western Protestant debate in forensic style. From the Eastern orthodox theological debate, theosis is used in accordance to what the church father Irenaeus meant: 'God became human that we might become divine'. This article gives a definition of theosis, sketch the historic background of the concept, discuss salvation in the Western theological tradition, and pays attention to a theosis scriptural basis. Furthermore, attention is also given to Martin Luther and theosis as an indication that his view of salvation was much closer to theosis as was readily accepted in the Western theological debate since the Reformation of the 16 th century.

Keywords: Theosis; Eastern-Orthodox; Western-Protestant; Theological debate; Luther.

\section{Inleidend}

Meegaande artikel wil die betekenis van theosis in historiese en saaklike verband nagaan en met die bekende reformatoriese uitgangspunt met betrekking tot die regverdigingsleer (vgl. Rom 1:17) vergelyk. Die bedoeling is om aan te dui dat theosis waarskynlik meer bewustelik waardeer kan word as wat tot nog toe gebeur het. Daarom word in die artikel ook aandag aan die historiese aanloop gegee, as aanduiding van die feit dat theosis 'n relatiewe lang aanloop het wat reeds by die kerkvaders aanwesig was.

Die belangstelling in theosis $(\theta \varepsilon \omega \sigma \mathrm{s})$ word gewoonlik met die Oosters-Ortodokse spiritualiteit geassosieer en om hierdie rede is die tema in die Westerse teologiese debat ietwat minder gebruiklik. Theosis is vir die meeste Westerse teoloë onbekend, of indien bekend, dan onwelkom of verdag, aangrensend aan dwaalleer, veral in die lig van die feit dat vergoddeliking ter sprake kom (Gorman 2015:262). Die begrip het te make met menslike identiteit en die verwerkliking van die besondere aard daarvan wat sodoende in die vooruitsig gestel word. Daarom getuig theosis van die besondere en dikwels onverklaarbare misterie van die bemoeienis van God met die mens.

Die woord kom nie in die Nuwe Testament voor nie, maar dit geld ook vir die begrip drie-eenheid in verband met die Triniteit wat as sodanig nie in die Nuwe Testament gevind word nie. Ten spyte daarvan geniet drie-eenheid wye aandag in die teologiese debat (vgl. Payton 2007:1676-1678). Die begrip en wat daarmee verwoord word, kan onder andere ver teruggevoer word na die kerkvader Irenaeus (130-202; vgl. Skinner 2016:1350). Sy bekende uitspraak dat God mens geword het in Christus sodat mense goddelik kan word, spreek mee in dié verband en dui aan dat die gedagtekompleks wat deur theosis verwoord word, ouer en bruikbaarder is as wat vermoed word (Peacocke 1993:189). Die aard van goddelik-menslike identiteit kom nie daarop neer dat mense gode word of dat menslike identiteit in die goddelike opgelos word nie. 'We became the same as God but different, a unity in diversity through participating in the divine energies' (Kharlamov 2011:6).

Dit was nie 'n woord wat uit die Christelike tradisie voortgekom het nie, maar is langsamerhand met 'n Christelike inhoud gevul (Kärkkäinen 2004:3). Die uitdaging van die Christelike teologie lê nie net in onderlinge diskussie met ander tradisies nie, maar volgens Polkinghorne (1991:103) ook daarin dat die Oosters-Ortodokse teologie korrek mag wees dat die uiteinde van die skepping in volledige vergoddeliking (theosis) te vinde is. 
Westers-Protestantse en Rooms Katolieke teoloë is in gesprek met Oosters-Ortodokse teoloë oor theosis. Waar die debat aanvanklik toegespits was op Patristiese studies en 'n gesprek met die Oosterse Christendom, word die debat tans gevoer oor die spektrum van meer as een-en-'n-halwe millennium, waar die werk van prominente teoloë sedert Athanasius (293-373), die Kappadosiërs, Martin Luther, Johannes Calvyn en Karl Rahner onder andere aandag geniet (Christensen \& Wittung 2007:11).

Die betekenis wat aan theosis in die Oosterse debat verleen word, teenoor die Westerse siening oor geregtigheid, gaan wesenlik oor die eenheid met God. Hoewel theosis in die Oosterse tradisie prominent sedert die kerkvaders gefunksioneer het, is die begrip en wat daardeur verwoord word, nóú aan die regverdigingsleer in die Westerse teologiese tradisie verwant. Ninan (2017) wys in hierdie verband daarop met sy mening:

Christian theologians have long discussed 'theosis' (literally, 'becoming a god') as a final stage of salvation, when human beings have real union with God. The idea is virtually unknown among Protestants; but the goal of salvation described in terms of 'theosis' or 'deification' is at the heart of Eastern Orthodox theology, as inherited by Byzantine and Greek patristic theologians. We might say that theosis is to the Orthodox as justification is to the Protestant. (p. 96)

\section{Theosis: Enkele werksdefinisies van die begrip theosis}

By die nagaan van literatuur oor hierdie begrip en sy betekenis word dit duidelik dat die debat reeds vir'n redelike tyd aan die gang is, hoewel dit nie noodwendig vir SuidAfrika geld nie. In hierdie opsig word na definisies van die begrip verwys soos dit in die teologiese debat reflekteer ter opheldering van wat met theosis bedoel is. Dit is begryplik en 'n mens kan verwag dat gevra sal word na die betekenis van theosis, wat veral in die Oosterse teologiese debat nie vreemd is nie.

McGuckin (2007) gee 'n werksdefinisie wanneer hy theosis beskryf as:

the sanctification of Christians whereby they become progressively conformed to God; a conformation that is ultimately demonstrated in the glorious transfiguration of the 'just' in the heavenly kingdom, when immortality and a more perfect vision (and knowledge and experience) of God are clearly manifested in the glorification (doxa) of the faithful. (p. 95)

Gorman (2009) se mening is:

Rather, theosis means that humans become like God. The tradition of theosis in Christian theology after the New Testament begins with the famous dictum of Irenaeus, later developed by Athanasius: 'God became what we are to make us what he is'. Theosis is about divine intention and action, human transformation, and the telos of human existence - union with God. (pp. 62-64)

Gorman (2015:7) definieer die begrip verder wanneer hy aandui dat theosis ook nou aan die kerk se missionale arbeid verbind kan word. 'I believe that theosis and other terms (deification, Christification, Christosis) adequately summarize this transformative reality of Spirit-enabled, Christ like participation in the life and mission of God'.

Kharlamov (2011) se siening en verstaan van theosis blyk uit sy uitspraak:

Theosis testifies to the inexplicably grand mystery of God's divine intimacy with human beings. Deification penetrates all spheres of human existence and can be seen as an answer to most pending ultimate questions. (p. 1)

Eenvoudig gestel kom dit daarop neer dat vergoddeliking 'n proses van heiligmaking is waardeur Christene stelselmatig tot God omvorm word. Hoewel die begrip soos gestel, nie in die Nuwe Testament voorkom nie, word verskillende Skrifuitsprake aangewend as aanduiding van die feit dat theosis (of stelselmatige vergoddeliking) tóg in die Nuwe Testament aanwysbaar is. In hierdie verband het Gregorius van Nazianze byvoorbeeld verskoning aangebied vir die feit dat hy tog die begrip aangewend het as 'n samevatting van die skriftuurlike boodskap (McGuckin 2007:96).

\section{Historiese agtergrond en aanloop}

Alexandrynse teoloë soos Clement, Origenes en Athanasius gee veral 'n soteriologiese basis aan die begrip, deur die verbinding aan die vleeswording van die Goddelike Woord sodat die volle mensheid verhoog kan word tot die misterie van persoonlike vergoddeliking. Die teologiese oorsprong van theosis (Ninan 2017:1146; vgl. ook McGukin 2007:97) kom in die Alexandrynse tradisie voor en verbind daarmee die kategetiese skool van Alexandrië wat sedert 180 dateer:

Beginning primarily with Clement of Alexandria (150-215 a.d.), the doctrine developed extensively until it reached its climatic formation in the writings of Cyril of Alexandria (376-444 a.d.), before Alexandria took a major turn in history after the Council of Chalcedon [451].

McGuckin $(2007: 97,99)$ wy besondere aandag aan twee van die Kappadosiërs, naamlik Gregorius van Nyssa (330-395) en sy vriend Gregorius van Nazianze (329-390), albei prominent in die voorgeskiedenis en aanloop van die begrip.

Blackwell (2010:22) maak 'n keuse vir Irenaeus en Cyrillus van Alexandrië as die patristiese skrywers wat medeverantwoordelik was vir die vestiging van theosis in hierdie teologiese debat. Blackwell wys egter daarop dat die begrip met verloop van tyd ontwikkel het en dat daar 'n nuanseverskil is tussen woordvoerders wat nader aan die Pauliniese tradisie geleef het, teenoor diegene wat later gevolg het. Daarom het die theosis-debat (deification) met verloop van tyd ontwikkel soos deur verskeie woordvoerders verwoord is.

Blackwell maak derhalwe 'n keuse vir Irenaeus en Cyrillus uit 'n aantal woordvoerders wat ook in hierdie verband 'n bydrae gelewer het. Blackwell kies Irenaeus uit 'n eerste groep woordvoerders tussen die jare 150-300 op grond van 
die feit dat hy konstruktiewe gebruik maak van Pauliniese tekste. McGukin (2007:96) waardeer Irenaeus soortgelyk op grond van sy ontwikkeling van die begrip 'with freshness of insight, from the scriptural bases'. Vir Blackwell staan Gregorius van Nazianze uit as die skrywer wat theosis die meeste gebruik en ontwikkel het. Gregorius verbeter selfs op die bekende uitspraak van Athanasius met die volgende uitspraak: 'And since, then, God is made man, so man is perfected as God, and that is my glory' (McGukin 2007:101).

Uit 'n latere generasie (300-451) val Blackwell se keuse op Cyrillus as 'n keuse tussen Cyrillus, Athanasius en Didimus (313-398). Hy kies egter Cyrillus as die jongste van die drie wat in die Alexandrynse tradisie staan en die gedagtelyn van die vorige twee verder gevoer het. Behalwe dit, was hy ook 'n uitstaande eksegeet (Blackwell 2010:23-25).

Kärkkäinen (2004:21) verwys na Gregorius van Nyssa in verband met die vraag of 'n kind wat vroeg sterf nie beter daaraan toe is nie, aangesien sodanige kind minder aan die sonde blootgestel was. Sy antwoord was dat die menslike bestaan in die ewige lewe nie rondom geregtigheid, beloning of straf wentel nie, maar dat God se bedoeling is dat gelowiges aan hulle skeppingsdoelwit voldoen, naamlik om deel te neem aan God se lewe. Die aardse lewe is om nou reeds te groei en te streef na hierdie ewige gemeenskap. Vanuit hierdie perspektief is dit begryplik dat volgens Irenaeus, 'God originally intended that humans would enter into theosis through a natural process of growth'.

Die sondeval is derhalwe anders gesien, naamlik as 'n individuele keuse van Adam en nie kollektief vir almal daarna nie. Erfsonde is onmoontlik, en dood het die beeld van God vertroebel. Die kruisdood van Christus was dus nie straf van die een regverdige nie, maar as die dood van die vleesgeworde Heer. Die bedoeling was nie om te voldoen aan 'n juridiese eis as betaling vir die sonde nie (Anselmus), maar om dood te verslaan en te oorwin. Die Oosterse teologie werk dus nie met 'n 'Pauliniese regverdigingsleer' nie en dink ook nie volgens Anselmus se leer van satisfaksie nie. Die gevolge van die sondeval, die fisiese dood en die skending van die beeld van God, verg 'n terugkeer na onsterflikheid, asook 'n herstel van die beeld van God.

Verlossing van sonde is nie onbelangrik nie, maar is 'n terugkeer na onsterflikheid en 'n omvorming tot die beeld van God. Die begrip soteria in die Nuwe Testament, word aangewend as aanduiding van die volheid van 'n lewe in God wat bokant verlossing, versoening en geregtigheid uitgaan (Kärkkäinen 2004:22-24).

Die twee patristiese tekste wat die meeste aangehaal word, is dié van Irenaeus en Athanasius. Irenaeus verklaar (soos aangehaal deur Kärkkäinen 2004):

The word of God, our Lord Jesus Christ ... did through His transcendent Love, become what we are, that He might bring us to be even what He is, Himself. (p. 24)
Athanasius stel: 'He, indeed, assumed humanity that we might become God'. Hy beklemtoon ook dat die volle goddelikheid van die Woord daarop neerkom dat gelowiges in en deur Hom vergoddelik word (Kärkkäinen 2004:26).

Maximus (580-662) wat as die Belyer bekend geword het (vgl. Bakhuizen van den Brink 1965:236), beskryf theosis as die deelname van die héle mens met die héle God:

finally that the whole man should become God, deified by the grace of God-become-man, becoming whole man, soul and body, by nature, and becoming whole God, soul and body, by grace. (Kärkkäinen 2004:26-27)

Deur sy klem op die onsegbaarheid (ineffability) van die Triniteit, beklemtoon hy die wonder dat God die menslike bestaan binnegedring en die moontlikheid van meelewing geopen het, naamlik 'the trinitarian Godhead creates conditions for mutual indwelling in divinization', waardeur 'n resiproke verhouding tussen die drie-enige God en gelowiges gevestig is (Vishnevskaya 2007:142-143).

Volgens Blackwell (2010:22), voer woordvoerders uit 'n latere generasie 'n skerper omlynde debat oor theosis as diegene wat nader aan die Pauliniese tradisie geleef het. Theosis het die debat beïnvloed en daarom moet 'n mens daarop bedag wees hoe theosis in die Christologiese debat deur relevante outeurs ter sprake gebring is. Hier kan onder andere verwys word na die Ariaanse vraagstuk, wat deur die debat oor die goddelike en menslike natuur van Christus gevolg is, en na Origines (185-253/54) en sy 'subordinatiaanse Triniteitsleer'. Die verdere stryd in die Christologie word na Nestorius (428-431) genoem, wat uiteindelik in 430 tot ketter verklaar is (vgl. Bakhuizen van den Brink 1965:190-194). Die Sinode van Chalcedon (451) was die waterskeiding, nie net in die Christologiese gesprek nie, maar dit het ook kerklike verdeling verhaas. 'The fundamental trait of the religious hopes expressed in the soteriology of the early Eastern Church was the yearning for physical renewal through participation in the Divine nature' (Kharlamov 2011:43).

Die vrywillige vernedering as verlossende kenosis van die Seun van God, moes plaasvind sodat die gevalle mens kon opleef na hulle theosis, of vergoddeliking (Kärkkäinen 2004:30). Oosterse teologie het die noodsaak van verlossing gesien as 'n verlossing uit die doodsbestaan, wat tot nadeel van die ewige lewe strek. Vergoddeliking was meer as bloot metafories, maar beklemtoon die eenheid met God as 'n realiteit vir gelowiges.

Die twee teenoorstaande identiteite van God en mens was moeilik versoenbaar, en daarom is beklemtoon dat God steeds God is en mens steeds mens bly in die deelname aan die wese van God. Daarom is gepoog om die probleem te oorbrug met die onderskeid, soos dit deur Kärkkäinen (2004) gestel is:

... divine essence and divine energies. According to the Eastern understanding, deification means participating in divine energies, not the divine essence as such. ... Maximos the 
Confessor states it accurately: All that God is, except for an identity in ousia [essence], one becomes when one is deified by grace. (pp. 30-31)

Alhoewel die realisering eers in die ewigheid sal geskied, word tog klem geplaas op die noodsaak daarvan wat nou reeds in die huidige bestaan moet gebeur. Daarom het Oosterse teoloë nie daarvan weggeskram om van 'divinehuman synergy, the cooperation of the person with God' te praat nie. 'Men and women are saved by grace, but not without one's total devotion and willingness to be transformed' (Kärkkäinen 2004:31).

Die rol van die Heilige Gees kom ter sprake in die werk van Athanasius, Gregorius van Nazianze, Gregorius van Nissa, asook Cyrillus van Alexandrië, wat beklemtoon het dat die Gees lewe aan die vlees gee. Daar is in die Oosterse tradisie derhalwe 'n noue verband gelê tussen theosis en die Heilige Gees. Die neerdaling of katabasis van Christus het gelowiges dus in staat gestel om 'n anabasis of opgang deur die Heilige Gees te ervaar (McGuckin 2007:96).

Een van die kenmerkende momente in die Oosterse teologie is dus in die verstaan van die skepping en die uiteindelike menslike toekoms te vinde, wat onskeibaar is van die pneumatologie (Meyendorff 1974:11). Verlossing is gesien as 'n deelname aan vergoddelikte menslikheid van die vleesgeworde Logos. Die Gees is as die beeld van die Seun van God bestempel, wat vir hulle daarop neerkom dat die Gees gemeenskap met God moontlik maak. Kärkkäinen (2004:26-27) meen dat veel meer tekste aangehaal kan word, ook uit die geledere van die Kappadosiërs, asook Basilius (330-379) en Macarius (-390), wat die proses van vergoddeliking aan die Heilige Gees toeskryf.

Volgens Athanasius het die Seun die eerste vrug van die Gees geskenk, sodat gelowiges tot kinders van God volgens die beeld van die Seun van God verander kan word (Skinner 2016:1483). Die lyding en onderrig van Jesus is niks anders nie as die neerdaling van die Heilige Gees op die kerk. Kenmerkend van Gregorius van Nazianze en Basilius, is dat die besondere attribute van genade deur hulle aan die Gees toegevoeg is soos vergoddeliking, vervolmaking, aanneming en heiliging. Die Heilige Gees kommunikeer dit wat goddelik is tussen die Vader en die Seun aan gelowiges in die kerk, waardeur hulle deelnemers word aan die goddelike natuur. Gregorius van Nazianze stel dit duidelik dat vergoddeliking (deification, theosis) die hoogste gawe en seën van die Heilige Gees uitmaak (Tsirpanlis 1979:168). Die aspek van vergoddeliking word dus nie net Christologies uitgedruk nie, maar verg ook 'n pneumatologiese ontwikkeling.

Gregorius van Nyssa, die broer van Basilius, ontwikkel die leer van die goddelikheid van die Heilige Gees op grond van sy leer van die verlossing. Geskoei op die standpunte van Basilius en Athanasius, is hy van mening dat verandering (morphosis) van die Christen en vervolmaking (teleiosis) die werk van die Heilige Gees is; 'the Spirit therefore is consubstantial with the Son and the Father. In other words, there is a unity of nature but a distinction between hypostases' (Congar 1997:31-32).

Die matige onderwaardering van die Heilige Gees in die Westerse teologie is waarskynlik aan Anselmus (onder andere) te wyte, tot nadeel van die Heilige Gees wat sodoende by implikasie, ondergeskik aan die Seun geplaas is. Westerse denke oor die verlossingsleer toon dikwels 'n sterk Christosentriese klem tot nadeel van die pneumatologie (Kärkkäinen 2004:32). Selfs Barth het hierdie argument toegegee, as antwoord op 'n student se navraag waarom die Heilige Gees grootliks in Barth se gedeelte oor die geopenbaarde Woord afwesig is (Bender 2013:277; vgl. Thompson 1991:8, 198).

\section{Die regverdigingsleer in die Westerse teologiese tradisie}

Die Griekse woord vir regverdiging en sy verwante, kom 33 keer in die Nuwe Testament voor, terwyl frases wat op die eenheid met Christus, in Christus, of in Hom dui, meer as 140 keer aangetref word. Westerse teoloë is derhalwe van mening dat die begrip, een met Christus, dien as 'n 'overarching category within which all the other elements of the application of salvation play their various roles'. Geen Westerse tradisie het in die sogenaamde ordo salutis dit in die vooruitsig gestel, dat daardeur ' $n$ eenheid in Christus volg nie, terwyl dit juis is wat deur theosis in die Oosterse teologiese tradisie verwoord word (Payton 2007:1667).

Die regverdigingsleer, as prominente geloofsartikel van die Reformatoriese teologie waarop die kerk staan of val, is in die laaste jare vanuit die Nuwe-Testamentiese wetenskap ernstig ondersoek (Kärkkäinen 2004:10; vgl. Gorman 2009:403). Sanders (1977), maar ook Dunn (1992:2), is van mening dat die regverdiging deur die geloof wat reglynig aan Luther toegeskryf is, 'n beduidende misverstand inhou ten opsigte van Paulus, maar ook nie minder ten opsigte van regverdiging deur die geloof nie. Daarby bedoel hy nie dat dit noodwendig verkeerd is nie, maar waarskynlik eensydig en mislei is deur twyfelagtige aannames. Gorman (2009) verwoord sy mening oor die verskuiwing met sy opmerking:

This re-thinking of Luther and other Reformers has shifted the emphasis in Reformation soteriology from declaration and legal fiction to real participation and even 'divinization' - a term found even in Luther. So too in the study of Paul: there is foment and re-thinking, especially about the relationship between faith and participation. (p. 413)

Dunn (1992:3-6) verwys opsommend na die aangeleenthede wat die Nuwe-Testamentiese wetenskap wil bespreek, naamlik dat Luther Paulus se bekering as die klimaks van 'n lang innerlike stryd sou gesien het; verder dat Luther die regverdigingsleer in individuele terme sien; of dat Paulus se ontdekking van geregtigheid deur geloof, vir Luther 'n wegdraai van Judaïsme beteken het. Daarom beskou Luther die Judaïsme van die Nuwe-Testamentiese tydvak as 
'n agterhaalde religie wat Luther ook ten opsigte van die Roomse siening van sy tyd nagehou het.

Vir Dunn (1992:10) is Paulus se bekering nie die gevolg van 'n bepaalde sielewroeging op grond van sy verlede nie, maar omdat hy die belewenis as 'n roeping ervaar het (change agent) (vgl. Malina \& Pilch 2013:235), veral om die evangelie ook aan nie-Jode te verkondig (vgl. Hand 9:15; 22:14-15; 26:16-18). Met verloop van tyd het in die Westerse teologiese debat, op grond van Luther se individualistiese verstaan van sy bekering, ook die toepassing op Paulus se 'bekering' gevolg en derhalwe ook in die Westerse teologiese debat (Kärkkäinen 2004:11). Verder is die Joodse agtergrond in die debat tot 'n groot mate misgekyk, asook die feit dat Paulus se onderrig op die $\mathrm{Ou}$ Testament as agtergrond gebaseer was. Geregtigheid in die Ou Testament was 'n relasionele begrip. Geregtigheid is nie 'n eienskap wat iemand bo en naas ander individualisties bekom het nie, maar eerder om aan die verwagting te voldoen wat iemand anders, die gemeenskap aan iemand stel.

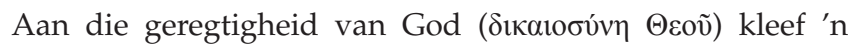
bepaalde voorrang wat reeds in die inleidende sin van die Wet hoorbaar is, naamlik dat Hy die Here is wat sy volk uit die slawerny verlos het (Eks 20:2). Die genadeverbond is God se inisiatief om te herstel en te behou wat aan Hom behoort. Menslike reaksie volg daarop en gevolglik is goeie werke die vrug van God se dade en nie die legitimering daarvan nie. Die dispuut in Reformatoriese verband was en is steeds of die geregtigheid van God 'n subjektiewe of 'n objektiewe genitief is, en of die werkwoord, om te regverdig op regverdigmaking óf regverdig ag neerkom, wat ook deel van die debat tussen Rooms Katolieke en Protestante gevorm het (Dunn 1992:17; vgl. Bultmann 1961:285). Wright (1991:148-151) wys daarop dat die verbondsmatige onderbou juis die agtergrond is wat in gedagte gehou moet word. Die verskil in die bedeling tussen die Ou en Nuwe Testament was dat die grense van die verbond in die Ou Testament deur eksterne grense getrek is, terwyl geloof in die Nuwe Testament bepalend is.

Vanuit die Ou-Testamentiese agtergrond is van ontvangers van die geregtigheid verwag om gepas teenoor God te reageer, maar ook teenoor die naaste. Geregtigheid het dus 'n vertikale en horisontale dimensie. Dit is van betekenis om in gedagte te hou dat die omgee vir die naaste ook die vreemdeling ingesluit het (Lev 19:18, 34) soos wat Jesus ook vyande as naaste getipeer het (Matt 5:43-48).

Kärkkäinen (2004) som die Nuwe-Testamentiese debat soos volg op: regverdiging is een van die vele beelde in die Nuwe Testament en kan nie as die hermeneutiese sleutel verhef word nie; die begrip dikaiosyne beteken geregtigheid van God; geregtigheid en heiliging kan nie van mekaar losgemaak word soos die Reformatoriese teologie - in teenstelling met die Roomse- en Oosterse teologie - gedoen het nie; Joodse religie behoort herevalueer te word in die lig van die Jesusen Pauliniese onderrig; geregtigheid is ' $n$ nuwe status en verhouding tot God in Christus deur die Heilige Gees, en selfs al word ' $n$ individuele reaksie gevra, is dit meer as dit:

it is integrally related to God's saving purposes for the covenant community and to the coming of the kingdom of God. Righteousness is thus also a relational concept, being right with God and other people. (p. 16)

\section{Skriftuurlike uitsprake wat met theosis in verband gebring word, met besondere verwysing na die Pauliniese literatuur}

Dit is vanselfsprekend, en met betrekking tot die debat as geheel van wesenlike belang, om te vra na die skriftuurlike gronde van die begrip theosis en die mate waarin die begrip en die gevolglike aanname op grond daarvan, Skriftuurlik ondersteun word. Die mees radikale uitspraak waarna verwys word en uit die $\mathrm{Ou}$ Testament afkomstig is, is die uitspraak in Psalm 82:6: 'Ek het self gesê julle is gode, seuns van die Allerhoogste, julle almal'. ${ }^{1}$ Teksgedeeltes uit die Evangelies volgens Matteus, Lukas en Johannes word ook ter sprake gebring. Uitsprake soos 'Wees dus volmaak soos julle hemelse Vader volmaak is' (Matt 5:48), 'die koninkryk van God is in julle midde' (Luk 17:21), en 'Staan daar nie in julle wet geskryf, "Ek het gesê julle is gode" nie?' (Joh 10:34), is aanhalings van die uitspraak uit Psalm 82:6 waarna verwys is. 'The Luke text indicates an indwelling divine potential; the Matthew text suggests continuous transformation into Godlikeness; the John text seems to intend the divinization of believers' (Finlan 2011:21).

Finlan is oortuig dat daar geen twyfel is nie dat theosis of vergoddeliking (deification) - gelowiges wat 'n goddelike natuur aanneem - in die Patristiese literatuur voorkom. Eweneens is daar ook nie twyfel dat die tema in die Pauliniese literatuur aanwysbaar is nie. Diegene wat Hy reeds vooruit gekies het, is ook vooruit bestem om aan die beeld van sy Seun gelykvormig te word (Rom 8:29), omdat almal na dieselfde beeld verander word (2 Kor 3:18). Finlan (2007:68) meen dat alle definisies van theosis nie noodwendig op Paulus sal pas nie. Hy beklemtoon die begrippe spiritual en glorious body wat in die beroep op Paulus, theosis of divinisation weergee. Finlan verwys na tekste soos 1 Korintiërs 15:35-54 op grond waarvan hy in gesprek tree met Wright (vgl. Wright 2003:69-71). Hy verwys egter ook na 2 Korintiërs 5:1-10 (Finlan 2007:70) asook Filippense 3:10, waarna hy stel dat die uitspraak in Romeine 8:29 wat op bestem wees 'om gelykvormig aan die beeld van sy Seun te word', dui, wel as theosis getipeer kan word (Finlan 2007:72). Dit is betekenisvol dat Finlan (2007:74) daarop wys dat theosis op konformasie aan Christus as 'n anastiform experience dui, 'n woord na aanleiding van ảvó $\sigma \tau \alpha \sigma \iota \varsigma$, opstanding. Met verwysing na 2 Korintiers 5:21 stel hy dat theosis gebeur by voltooiing van die regverdingsproses waarna die uitspraak verwys. Hy meen dit kan as oordrywing bestempel word, maar dui op

1.Skrifverwysings in meegaande artikel is geneem uit die Nuwe Testament en Psalms: 'n Direkte vertaling (2014) van die Bybelgenootskap van Suid-Afrika, tensy anders vermeld word. 
transformasie van 'n gelowige as 'n sentrale tema in die Paulus-onderrig. ' $n$ Gesprek oor theosis in die Pauliniese literatuur kan die offerplekverwisseling (sacrificial interchange) wat deur die dood van Christus bewerkstellig is, en die gevolglike deelname van 'n gelowige aan die kruisiging van Christus waardeur gelowiges deel in die opstanding om Christus wil, nie buite rekening laat nie. Dit begin reeds in hierdie lewe wanneer gelowiges tog daarin slaag om die wil van God te onderskei en verander word na 'Christlikeness, which can truly be called theosis' (Finlan 2007:78).

Die werklike daad van verlossing is deur Christus verrig toe almal hopeloos in sonde verlore was. Hom het God daargestel

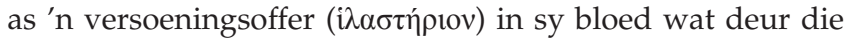
geloof verkry word (Rom 3:25). Sy dood was soos 'n offer waardeur die gemeenskap gereinig is, as antwoord op die impak van die sonde. Daar is dus ' $n$ bepaalde gang vir gelowiges in die gebeure wat deur God in Christus geïnisieer is. Iets soortgelyks word in 2 Korintiërs 5:21 verwoord, naamlik: 'Hy wat nie sonde geken het nie, Hom het God ter wille van ons sonde gemaak, sodat ons in Hom voor God regverdig kon word.' 'Paul mixes his metaphors: Christ is a new sacrifice of purification; and He is a new scapegoat who carry away $\sin ^{\prime}$ (Finlan 2007:78).

Wright (2013:1021) is selfs van mening dat Paulus se soteriologie as theosis beskryf moét word. Blackwell (2010:98) wys in hierdie verband daarop dat sowel Ireaneus as Cyrillus in die besonder van Paulus gebruik gemaak het.

\section{Gorman (2009) haal Paulus hieroor aan:}

For Paul, to be one with Christ is to be one with God; to be like Christ is to be like God; to be in Christ is to be in God. At the very least, this means that for Paul cruciformity - conformity to the crucified Christ - is really theoformity, or theosis. (p. 55)

Gorman (2009:31) meen dat God vir Paulus cruciform is; en as dit so is, dan is cruciform gelyk aan 'theoformity', of soos dit veral in die Oosterse tradisie neerslag gevind het, deification, divinisation of theosis. Gelykvormigheid (conformity) aan Christus, of heiligheid as deelname aan God, dui op inwoning (inhabiting) by die gekruisigde God. Theosis kan ook as heiligheid tipeer word, wat nie'n aanhangsel aan geregtigheid is nie, maar veel eerder gesien kan word as geregtigheid wat voltrek en effektief word.

Gorman (2015:261) gee toe dat die begrip theosis nie vir almal aanvaarbaar is nie en dat die noue verbinding wat hy lê tussen Paulus, soos verwoord in die brief aan die Romeine, en theosis vreemd mag klink. Tog is hy oortuig dat theosis die sentrale tema van die brief is ' - becoming like God by participating in the life of God -'. Christus het geword wat gelowiges is (Adam; vgl. Rom 5:14), sodat gelowiges kon word wat $\mathrm{Hy}$ is, die ware beeld van God. Christus het mens geword sodat mense deur sy dood en opstanding soos Hy kon word. Die siening om soos God te word, is waarskynlik in die Westerse tradisie ietwat vreemd, maar steeds vry algemeen in die Oosterse tradisie. Hooker (2008:19) is ook van mening dat die siening nie net Oosters is nie, maar wesenlik Paulinies soos verwoord in die Romeinebrief en wat as samevatting van Romeine 5-8 gesien kan word. Hierby sluit Wright (2013) aan in sy mening dat Paulus se soteriologie nie net as theosis gesien kán word nie, maar so tipeer moét word:

If the spirit of the living God dwells within his people, constituting them as the renewed tabernacle (or the new temple ...) then the work of his transforming spirit can and must be spoken of in terms, ultimately, of theosis, 'divinization'. (p. 1021)

Young (1990:433-446) het reeds die mening geboekstaaf dat die Romeinebrief in die lig van die tweede brief aan die Korintiërs gelees moet word, aangesien die Romeinebrief bepaalde temas in die tweede Korintiërbrief verder ontwikkel, wat met Paulus se verdediging van sy apostelskap te make het. Die tweede Korintiërbrief vertoon ten minste drie uitsprake (2 Kor 3:18; 5:21 en 8:9) wat met theosis in verband gebring kan word, met besondere klem op 2 Korintiërs 3:18:

En ons almal, terwyl ons met ontsluierde gesig die heerlikheid van die Here aanskou soos in ' $n$ spieël, word na dieselfde beeld verander, van heerlikheid tot heerlikheid, soos afkomstig van die Here, die Gees.

In al drie uitsprake kom Paulus se soteriologie van transformasie en regverdiging ter sprake.

Die brief aan die Romeine gaan oor theosis, meen Gorman (2015:264, 268). Die brief is 'n vroeë Christelike verhandeling oor theosis wat oor deelname, transformasie, temas van regverdiging en verheerliking handel wat ook in die tweede Korintiërbrief aangetref word. Gorman (2015) stel:

\footnotetext{
The subject of Romans is salvation (sōtēria): God's restoration of righteousness/justice (dikaiosynē) and glory (doxa) to unrighteous/unjust and glory-less humanity. Paul's soteriology of human dikaiosynē and doxa means participation in the divine dikaiosynē and doxa by participation in the death and resurrection of the Messiah Jesus, God's righteous and now glorified Son. (p. 268)
}

In die verloop moet gestel word dat gelowiges nie aan God gelyk word nie. Watter goddelike eienskappe is dan tog moontlik? Die antwoord is ten minste heiligheid en onsterflikheid. Dit is soos 'n ysterstaaf in die vuur wat wesenlik onveranderd bly, maar tog verander omdat lig en hitte deur deelname bygevoeg word. Gelowiges kan dus nie onveranderd bly nie, maar moet uiting gee aan die effek van die verkondigde Woord wat naby gekom het en in eskatologiese transformasie voltrek word. Theosis is derhalwe 'transformative participation in the kenotic [self-emptying], cruciform character of God through Spirit-enabled conformity to the incarnate, crucified, and resurrected/glorified Christ' (Gorman 2015:269).

Blackwell (2010:105) beklemtoon die feit dat Romeine 1-8 'n verdere uiteensetting is van die bekende uitspraak

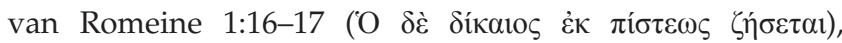


as aanduiding van die redding wat God skenk,'n omskrywing van die openbaring van God se geregtigheid. Die brief is 'n evangelie van goddelike geregtigheid in en deur Christus waardeur diegene wat glo, Jode sowel as nie-Jode, die lewe ontvang, 'n evangelie van God se geregtigheid en eer.

Die Petrus-uitspraak (2 Pet 1:4) word aangehaal ('sodat julle deel kan hê aan die goddelike natuur'). Dit dui op die eenheid met God as 'n realiteit van die seëninge van die tyd wat kom.

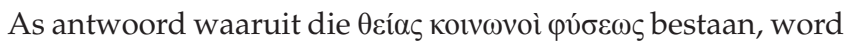
na vyf verskillende kwaliteite (5-7) verwys wat uit die beloftes spruit wat Christus gegee het. Dit is moontlik op

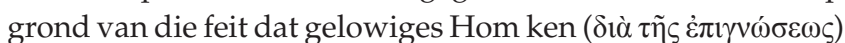
(3) wat meermale in die brief voorkom $(1: 2,3,8 ; 2: 20)$. Die

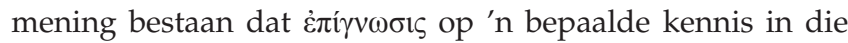
brief dui wat meer is as bloot $\gamma v \tilde{\omega} \sigma \mathrm{rc}$. 'It is an effective knowing of Christ, received at conversion, that leads ultimately to eternal life' (Starr 2007:83). Starr wys op die moontlikheid dat die skrywer sy teologie verwoord het om by sy hoorders aan te pas wat in 'n sosiale konteks was, waar 'n duidelike formulering van Paulus se onderrig oor die Christelike hoop, 'n sterk retoriese argument gevorm het (Starr 2007:90; vgl. ook Mannermaa 1998b:416; Skinner 2016:1102).

\section{Theosis en Luther (1483-1546)}

Daar het sedert die sewentigerjare 'n nuwe dimensie in die Luther-ondersoek ontstaan wat veral deur Mannermaa en sy studente aan die Universiteit van Helsinki geloods is. Christus se inwoning deur die geloof volgens Luther 'implies a real participation in God'. Dit korrespondeer met die Ortodokse leer van 'participation in God', naamlik theosis. Christus is in die geloof teenwoordig en is sodoende gelyk aan geregtigheid deur die geloof. Christus se teenwoordigheid in gelowiges het ' $n$ veel meer prominente plek ingeneem in Luther se teologie in vergelyking met die Lutheranisme wat gevolg het (Mannermaa 1998a:44-49).

Luther se siening oor regverdiging verskil van die tradisionele siening soos in die amptelike dogma in die EvangeliesLutherse kerke geformuleer is. Daar moet tussen Luther se eie geskrifte en 'n vergelyking met Lutherse belydenisskrifte en latere formulerings onderskei word. Melanchthon (14971560; vgl. Kooiman 1959:639-641; Steubing 1985:38) het 'n beduidende rol in die aanvanklike formulering van Lutherse belydenisskrifte gespeel, wat nie noodwendig ' $n$ poging tot formulering van 'n eie teologie was nie, maar eerder 'n reaksie teen Rooms-Katolisisme. Daarbenewens is sodoende ook nie volledig aan Luther se sienings uiting gegee nie. Mannermaa is van mening dat theosis een van die beelde is wat Luther gebruik het om verlossing te beskryf. Dit het vir die ekumeniese kerklike lewe 'n besonder kreatiewe uitdaging daargestel, en die pneumatologiese potensiaal van die Luther-teologie ontbloot. Tradisioneel het die siening ontstaan dat Luther se regverdigingsleer 'n forensiese toerekening is van Christus se regverdiging deur die geloof. 'n Forensiese regverdigingsleer het die uitstaande kenmerk geword in Luther se teologie in dié mate dat dit as die onderskeidende element van Luther se regverdigingsleer teenoor die Rooms-Katolisisme gesien is.

Daar is 'n wesenlike verskil in die regverdigingsleer van Luther in vergelyking met die amptelike Luther-dogma soos deur konfessionele bronne van die Lutherse kerke verwoord is. Die Mannermaa-navorsing (Kärkkäinen 2004):

claim that for Luther the doctrine of justification is not a forensic term but rather a matter of Christ abiding in the heart of the believer in a 'real-ontic' way ... (pp. 37-38)

Die Mannermaa-skool is daarom van oortuiging dat theosis, behalwe 'n vreemde Ortodokse konsep, eintlik 'n begrip was wat deur Luther aangewend is om regverdiging te beskryf.

Dit word as ' $n$ bate van die Finse navorsing gesien dat in die wyse waarop Luther theosis verstaan het (as 'n noue verhouding tussen gelowiges en Christus), geloof as die bron van vergoddeliking (theosis) funksioneer. Klem op Woordverkondiging en die bediening van die sakramente in die onderhoud en versterking van die geloof, was in diens van die dinamika tot regverdiging, wat tot theosis gelei het (Linman 2007:189).

Die navorsing van Mannermaa (1998b:354) word as 'n deurbraak in Luther-navorsing beskou, aangesien Christus in geloof teenwoordig is (in ipsa fide Christus adest). Daardeur word standpunt ingeneem teen 'n forensiese uitgangspunt van regverdiging waarin Christus vir ons is (Christus pro nobis). Geloof is vir Luther'n werklike deelname aan Christus, en dit is deur die geloof dat 'n gelowige geregtigheid van God in Christus ontvang.

Luther sien Christus as 'n kollektiewe persoon (maxima persona) in wie alle mense verenig is. Christus is derhalwe elke sondaar, en dit loop daarop uit dat Hy die enigste sondaar (solus peccator) word. Hy is die grootste sondaar van almal, maar tegelyk die Woord wat vlees geword het, God wat volledig regverdig is.

Christus is God wat oor sy krag beskik, en regverdig en genadig is; Hy is lewe. Hierdie volkomenhede voer stryd teen die sonde en dood en word deur Christus oorwin. Hy het die stryd teen die sonde en geregtigheid oorwin waardeur die hele skepping verander is. Dit het vir gelowiges die gevolg dat geregtigheid beteken om in Christus te lewe. Gelowiges het deel aan Christus deur geloof waardeur hulle in die volheid van God deel. Volgens Luther is geregtigheid nie dit wat toegereken word op grond van geloof in Christus nie. Geloof is ' $n$ deelname aan Christus, in geregtigheid en lewe, want dit is wat Christus is. Geregtigheid deur die geloof beteken om deel te hê aan God deur Christus (Mannermaa 1998b):

The properties of God, which at the same time form the essence of God, are, for example, righteousness, wisdom, power, holiness, joy, peace, eternal life - and especially love. All these properties ... are present in their abundance in the person of Christ. (pp. 379-397) 
Op grond van God se liefde as agape, deel gelowiges in hierdie volkomenhede van God, wat terselfdertyd deelname aan Christus daarstel (Mannermaa 2005:1078). Christus is die objek van geloof, maar ook die subjek van geloof, omdat Christus in geloof self teenwoordig is (Mannermaa 1998b:428, 446). 'God changes the sinner ontologically in the sense that he or she participates in God and in his divine nature, being made righteous and "a god"' (Peura 1998a:568). Die uitspraak dien tot verdere opheldering van Luther se bedoeling met vergoddeliking of theosis.

Braaten and Jensen (1998) meen volgens die forensiese model van regverdiging dat ons regverdig is:

while in reality we are not. But if through faith we really participate in Christ, we participate in the whole Christ, who in his divine person communicates the righteousness of God. Here lies the bridge to the Orthodox idea of salvation as deification or theosis. (p. 25)

Tradisioneel is dus aanvaar dat die mees kenmerkende van die Luther-regverdigingsleer in die forensiese toerekening van Christus se regverdiging van die gelowige deur geloof bestaan. Forensiese regverdiging is as sodanig tot die uitstaande kenmerk van die Lutherse regverdigingsleer verhef as wesenlike verskil tussen Lutheranisme en Rooms Katolisisme. Dit kan ook as die verhouding of verskil tussen forensiese en effektiewe regverdiging, onderskeidelik getipeer word (Kärkkäinen 2004:51-52).

Die belangrikste bydrae van Mannermaa lê in die nuwe metodologiese raamwerk van Luther-navorsing. Daardeur word afstand van die neo-Kantiaanse onderskeiding geneem tussen 'God's "essence" and "effects",' wat daarop neergekom het dat God nie geken kan word nie, behalwe om die 'effects of God in our lives' te ken. Hierdeur is die betekenis van die werklike teenwoordigheid van Christus in Luther se denke onderwaardeer. Mannermaa argumenteer dat Luther se realistiese ontologie sodoende nie gereflekteer word nie, omdat daar vanuit 'n filosofiese konstruksie geredeneer word (Kärkäinen 2004:39; vgl. Braaten \& Jensen 1998:33; Linman 2007:190). Lutherse teoloë het die denke van die Lutherse belydenisskrifte gevolg waar grace en gift in die Lutherse denke van mekaar geskei is en eerder met ' $n$ forensiese aanslag gewerk word (Kärkkäinen 2004:56).

Luther het nie effektiewe en forensiese regverdiging van mekaar geskei nie, net soos 'grace' (gratia) en 'gift' (donum) twee kante van dieselfde saak verwoord. Eersgenoemde dui op die sondaar wat regverdig verklaar word (forensies), terwyl laasgenoemde aandui dat die sondaar regverdig gemaak word (effektief). Gratia en donum is eintlik albei dieselfde, naamlik die werklike regverdiging wat vrylik in Christus geskenk word (Kärkkäinen 2004:52; vgl. Mannermaa 1998b:403).

Luther onderskei tussen twee vorms van geregtigheid, naamlik die geregtigheid van Christus en die geregtigheid van die mens. Die geregtigheid van Christus is vreemde geregtigheid wat van buite die mens kom. Dit is die geregtigheid wat Christus in Homself is en so die mens regverdig maak. Dit gebeur sonder menslike toedoen, uitsluitlik uit genade (sola gratia). Dit is nie 'n forensiese toerekening nie, maar gelyk aan die geregtigheid van Christus wat in 'n gelowige realiseer. Hierdie geregtigheid bring eenheid tussen Christus en 'n gelowige (Kärkkäinen 2004:53; Peura 1998a:520).

Die geregtigheid van die mens (die gelowige) is geregtigheid wat ontvang word. Dit is die resultaat van die geregtigheid van Christus wat in die ontvanger effektief gemaak word. Die oorsprong van menslike geregtigheid lê buite die mens in die geregtigheid van Christus. Die geregtigheid van Christus wat aan die ontvanger geskenk word, dui die begin aan waardeur die effek van die sonde tot niet gemaak word. Die forensiese toerekening van Christus se geregtigheid maak nie die essensie uit van Luther se siening van geregtigheid nie. Christus is egter in die geloof teenwoordig en dit lei tot eenheid tussen Christus en 'n gelowige waardeur heiliging en regverdiging aan mekaar verbind soos deur Luther verwoord is. Dit is die geregtigheid in Christus wat in die hart van 'n gelowige deur geloof vestig. Dit is vreemde geregtigheid, omdat die oorsprong buite die mens is, maar dit is ook huidig, omdat dit die eiendom van die ontvanger word.

Luther beklemtoon die belang van Christus vir menslike geregtigheid, want die genade van Christus verwys na sy persoonlike genade. Dit is slegs Hy wat van alle 'mense' die enigste is 'who is in God's judgment favourable and acceptable. ... This means that God favours all of Christ's deeds as well'. Christus se persoon en wat Hy aan die kruis vermag het, kan nie van mekaar geskei word nie. Wat Christus sodoende moontlik gemaak het, word deel van gelowiges as die volle genadegeskenk tot geregtigheid van die sondaar (Kärkkäinen 2004:54).

Daar is dus 'n korrelaat tussen forensiese en effektiewe geregtigheid aan die een kant, en genade (gratia) en geskenk (donum) aan die ander kant. Wanneer die Formula of Concord (FC) stel dat die geregtigheid slegs God se guns ten opsigte van 'n gelowige insluit, dui dit op toegerekende en derhalwe op forensiese geregtigheid. Sodoende word Luther se siening oor donum verskraal, en die essensiële aspekte van effektiewe geregtigheid soos wedergeboorte, vernuwing, herlewing en God se teenwoordigheid in die sondaar, uit die regverdigingsleer uitgelaat. Gelowiges in wie Christus woon word dus om Christus wil regverdig verklaar, waarop geloof volg. Dit is nie die gevolg van geloof nie en derhalwe nie forensies nie (Kärkkäinen 2004:55-56; Peura 1998a:538-543).

Luther se mening oor geregtigheid het belangrike konsekwensies vir die naaste. Sy siening van God se liefde en die werklike teenwoordigheid van Christus in gelowiges, open 'n nuwe begrip en horison van naasteliefde. Die 
verhouding met God is nie meer op mense se liefde vir God gebaseer, waar na God toe beweeg word nie, maar veel eerder op die ontvangs van God se liefde in die geloof waardeur goeie werke sodoende in diens van die naaste geplaas word. Sy slotsom is uitdagend in die sin dat die teenwoordigheid van Christus in gelowiges, 'n Christen tot 'n werktuig van Christus omvorm - skerper gesien, 'n 'Christus' vir die naaste.

Die uitdaging is dus dat Christene sal doen soos wat Christus doen. Daarom: 'in ipsa fide Christus adest, the real presence of Christ in the believer' wat nie net geestelik of uitwendig (extra nos) is nie, maar werklik, met ons (in nobis). 'In fact, Luther says, then he is "one with us" and that "Christ lives in us through faith"' (Kärkkäinen 2004:58).

Luther se regverdigingsleer soos dit in die belydenisskrifte onder die leiding van Melanchthon geformuleer is, dui op 'n eensydige verstaan van sy teologie en onderwaardeer die betekenis van die Heilige Gees in die verlossingsleer. Deelname aan God is alleen moontlik deur die Heilige Gees as die Gees tot aanneming (Rom 5:5). Vergoddeliking (theosis) is 'n pneumatologies-gelaaide beeld van verlossing, 'n proses van toenemende heiligheid (vgl. Rom 8:11, 15; 1 Kor 13:13; 2 Kor 3:18). Die Heilige Gees as die Gees van Christus is die lewende, goddelike realiteit wat gelowiges ontmoet en 'n mistieke eenheid tussen sondaar en God drie-enig skep (Kärkkäinen 2004:63-64; vgl. Payton 2007:1651).

In Luther se eie woorde (Sermo de duplici iustitiae 1518; Mannermaa 1998a):

Thus the righteousness of Christ becomes our righteousness through faith in Christ, and everything that is his, even he himself, becomes ours ... and he who believes in Christ clings to Christ and is one with Christ and has the same righteousness with him. (p. 90)

\section{Slotsom}

Die bekende Pauliniese uitspraak in die brief aan die Romeine (1:17), het 'n belangrike rol in die Westerse teologie gespeel. Die uitspraak is ' $n$ aanhaling uit die Ou Testament (vgl. Hab 2:4) wat in die denke van Martin Luther 'n beduidende invloed uitgeoefen het (Van Aarde 2017:1). Luther se siening word selfs die 'lynchpin of Protestant theology' genoem (Skinner 2016:1976). In die uitspraak O $\delta \dot{\varepsilon}$

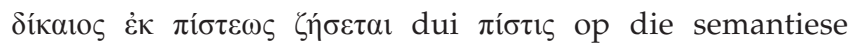
domein van vertroue en om te vertrou op, en daarom het die objek van vertroue die betekenis van geloofwaardig en betroubaar te wees. Daarom is lojaliteit, eerder as geloof,

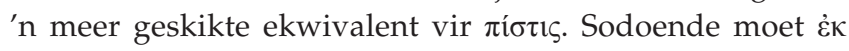

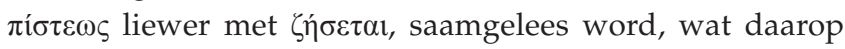
neerkom dat die regverdige van, of in die getrouheid van God leef (Van Aarde 2017:3). Derhalwe is dit God se geregtigheid wat in geloof ter sprake kom en dus vorm geloof nie 'n goeie werk van die belyer daarvan nie (vgl. Reumann 1999:34). 'n Ondersoek na die draagkrag van theosis dui aan dat die begrip veel breër aan die orde gekom het as wat oor die jare besef is, en veral in die Westerse teologiese debat gereflekteer is. In die lig van die aanwending van die bekende uitspraak in die Romeinebrief, is dit waarskynlik tog so dat die regverdigingsleer in die Westers-Protestantse teologie 'n swaarder forensiese klem gekry het as wat nodig is. Dit kan daarop uitloop dat geloof as menslike reaksie 'n sluitsteenbetekenis gekry het van regverdiging as ' $n$ handeling wat in Christus begin, maar effektief word met 'n gelukkige einde, wat as 't ware op die regte geloofskeuse berus.

Theosis en die herlees van Luther, wat vanuit Mannermaa op dreef gekom het, plaas Luther in 'n ander lig as wat normaalweg aanvaar is. Geloof is nie die nakoming van 'n bepaalde stelreël nie, maar 'n deelname aan Christus wat in sy goddelikheid die geregtigheid van God in gelowiges kommunikeer. Deur die geloof in Christus ontstaan 'n volledige ommekeer, waar die geregtigheid van God in Christus die sondeheerskappy oorwoeker. Geloof is vir Luther die volledige deelname aan Christus nie net in 'n formeel-uiterlike manier nie, maar werklik, van harte.

Dit is verder ook van betekenis om, wanneer theosis op die Skrif toegepas word, ook tot die slotsom te kom dat theosis inderdaad 'n skriftuurlike begronding het wat ten minste in die Oosters-Ortodokse tradisie, as sodanig funksioneer het.

Die rede waarom theosis nie algemene aanvaarding ontvang het nie, is waarskynlik in die vooropgestelde indruk geleë dat dit die bedoeling is dat mense wesenlik God word. Soos die Woord vlees geword het, is dit noodsaaklik dat vlees 'Woord' moet word. Luther se verstaan van theosis is nó aan sy teologie van die kruis verbind. Aan die kruis is nie net Christus ontledig nie, maar ook álle Christene, 'the passio through which one is emptied', gestroop van enige menslike poging tot selfregverdiging (Mannermaa 1998a:145).

Luther argumenteer vir 'n begrip van theosis as 'n sentrale deel van sy regverdigingsleer. 'Both aspects of justification, imputed righteousness as well as effective, transforming righteousness, are based on the indwelling of Christ and on our participation in him' (Peura 1998b:1051). Die rede waarom die oortuiging bestaan het dat die Lutherse en die Ortodokse siening van die regverdigingsleer nie versoenbaar was nie, is waarskynlik te vind in die feit dat Luther ontologies of metafisies en daarom fisies dink. Dit is lynreg teenoor 'n persoonlik-etiese en daarom relasionele siening, wat Protestante in die Bybel gevind, en in die Reformasie verwoord het (Mannermaa 1998b:317).

Theosis, soos vanuit die Oosters-Ortodokse debat verwoord, saamgelees met resente Luther-navorsing soos vanuit Helsinki geïnisieer, aan die hand van skriftuurlike getuienis wat die betekenis van theosis ondersteun, dui 'n besondere faset van die regverdigingsleer aan - ' $n$ faset wat anderkant ' $n$ rigiede forensiese regverdiging gevind word. 


\section{Erkenning \\ Mededingende belange}

Die outeur verklaar dat hy geen finansiële of persoonlike verbintenis het met enige party wat hom nadelig kon beïnvloed in die skryf van hierdie artikel nie.

\section{Outeursbydrae}

B.J.v.W. was die enigeste outeur betrokke by die skryf van die artikel.

\section{Etiese oorwegings}

Hierdie artikel volg alle etiese standaarde vir navorsing.

\section{Befondsing}

Hierdie navorsing het geen spesifieke toekenning ontvang van enige befondsingsagentskap in die openbare, kommersiële of nie-winsgewende sektore.

\section{Data beskikbaarheidsverklaring}

Data-deling is nie van toepassing op hierdie artikel nie, aangesien geen nuwe data in hierdie studie geskep of ontleed is nie.

\section{Vrywaring}

Die sienings en menings wat in hierdie artikel uitgedruk word, is dié van die outeur (s) en weerspieël nie noodwendig die amptelike beleid of posisie van enige geaffilieerde agentskap van die outeurs nie.

\section{Literatuurverwysings}

Bakhuizen van den Brink, J.N., 1965, Handboek der kerkgeschiedenis, 1e deel, Bart Bakker, Den Haag.

Bender, K.J., 2013, Karl Barth's Christological ecclesiology, Cascade, Eugene, OR.

Blackwell, B.C., 2010, 'Christosis: Pauline soteriology in light of deification in Irenaeus and Cyril of Alexandria', Durham theses, Durham University, Durham E-Theses Online, viewed 25 Julie 2018, from http://etheses.dur.ac.uk/219/.

Braaten, C.E. \& Jensen, R.W., 1998, Union with Christ: The new Finnisch interpretation of Luther, Eerdmans, Kindle edn., Grand Rapids, MI.

Bultmann, R., 1961, Theologie des Neuen Testaments, Mohr, Tübingen.

Christensen, M.J. \& Wittung, J.A., 2007, 'Introduction', in M.J. Christensen \& J.A. Wittung (eds.), Partakers of the divine nature, pp. 11-15, Baker, Grand Rapids, MI.

Congar, Y., 1997, I believe in the Holy Spirit, vol. 3, Herder, New York.

Dunn, J.D.G., 1992, 'The justice of God: A renewed perspective on justification by faith', Jounal of Theological Studies 43, 2. https://doi.org/10.1093/jts/43.1.1

Finlan, S., 2007, 'Can we speak of theosis in Paul?', in M.J. Christensen \& J.A. Wittung, Partakers of the divine nature, pp. 68-80, Baker, Grand Rapids, MI.

Finlan, S., 2011, 'Deification in Jesus' teaching', in V. Kharlamov (ed.), Theosis: Deification in Christian theology, vol. 2, pp. 21-40, Kindle edn., Wipf \& Stock, Eugene, OR.
Gorman, M.J., 2009, Inhabiting the cruciform God: Kenosis, justification, and theosis in Paul's narrative soteriology, Kindle edn., Eerdmans, Grand Rapids, MI.

Gorman, M.J., 2015, Becoming the gospel: Paul, participation, and mission, Kindle edn., Eerdmans, Grand Rapids, MI. (The Gospel and Our Culture Series).

Hooker, M.D., 2008, From Adam to Christ: Essays on Paul, Wipf \& Stock, Eugene, OR. Kärkkäinen, V., 2004, One with God, Liturgical, Collegeville, MN.

Kharlamov, V., 2011, Theosis. deification in Christian theology, Kindle edn., Pickwick, Eugene, OR.

Kooiman, W.J., 1959, 'Melanchthon', in F.W. Grosheide \& G.P. van Itterzon, Christelijke Encyclopedie, IV, p. 639-641 Kok, Kampen.

Linman, J., 2007, 'Martin Luther: "Little Christ for the world"; faith and sacraments as means to theosis', in M.J. Christensen \& J.A. Wittung, Partakers of the Divine nature, pp. 189-199, Baker, Grand Rapids, MI.

Malina, B.J. \& Pilch, J.J., 2013, Social-science commentary on the Deutero-Pauline Letters, Fortress, Augsburg, MN.

Mannermaa, T., 1998a, 'Why is Luther so fascinating? Modern Finnish Luther research', in C.E. Braaten \& R.W Jenson (eds.), Union with Christ: The new Finnish interpretation of Luther, pp. 36-275, Kindle edn., Eerdmans, Grand Rapids, MI.

Mannermaa, T., 1998b, 'Justification and theosis in Lutheran-Orthodox perspective' in C.E. Braaten \& R.W. Jenson (eds.), Union with Christ: The new Finnish interpretation of Luther, pp. 314-510, Kindle edn., Eerdmans, Grand Rapids, MI.

Mannermaa, T., 2005, Christ present in faith: Luther's view of justification, Kindle edn., Fortress, $\mathrm{MN}$.

McGukin, J.A., 2007, 'The strategic adaptation of deification in the Cappadocians', in M.J. Christensen \& J.A. Wittung (eds.), Partakers of the divine nature, pp. 95-114, Baker, Grand Rapids, MI.

Meyendorff, J., 1974, Byzantine theology: Historical trends and doctrinal themes, Fordham University Press, New York.

Ninan, M.M., 2017, Theosis: Partakers of divinity with God, Kindle edn., sl, sa.

Payton, J.R., 2007, Light from the Christian East: An introduction to the orthodox tradition, Kindle edn., InterVarsity, Downers Grove, IL.

Peacocke, A., 1993, Theology for a scientific age: Being and becoming - Natural, divine, and human, Fortress, Augsburg, MN.

Peura, S., 1998a, 'Christ as favor and gift (donum): The challenge of Luther's understanding of justification', in C.E. Braaten \& R.W. Jenson, Union with Christ pp. 511-775, Eerdmans, Grand Rapids, MI.

Peura, S., 1998b, 'What God gives man receives: Luther on salvation', in C.E. Braaten \& R.W. Jenson (eds.), Union with Christ, pp.844-1107, Eerdmans, Grand Rapids, MI.

Polkinghorne, J., 1991, Reason and reality: The relationship between science and theology, Trinity, Phildelphia, PA.

Reumann, J., 1999, 'Justification and justice in the New Testament', Horizons in Biblical Theology 21(1), 26-45. https://doi.org/10.1163/187122099X00029

Sanders, E.P., 1977, Paul and Palestinian Judaism: A comparison of patterns of religion, Fortress, Philadelphia, PA.

Skinner, A.C., 2016, To become like God, Publishers Printing, Salt Lake City, UT.

Starr, J., 2007, 'Does 2 Peter 1:4 speak of deification?', in M.J. Christensen \& J.A. Wittung (eds.), Partakers of the divine nature, pp. 81-92, Baker, Grand Rapids, MI.

Steubing, H., 1985, Bekenntnisse der Kirche, Brockhaus, Wuppertal.

Thompson, J., 1991, The Holy Spirit in the theology of Karl Barth, Wipf \& Stock, Eugene, OR.

Tsirpanlis, N., 1979, Greek patristic theology: Basic doctrines in Eastern church fathers, EO Press, New York. (Monograph series on orthodox theology and civilisation 3).

Van Aarde, A.G., 2017, "'By faith alone" (undivided loyalty) in light of change agency theory: Jesus, Paul and the Jesus-group in Colossae', HTS Teologiese Studies/ Theological Studies 73(3), a4355. https://doi. org/10.4102/hts.v73i3.4355

Vishnevskaya, E., 2007, 'Divinization as perichoretic embrace in Maximus the confessor' in MJ.'Christensen \& J.A Wittung (eds.) Partakers of the divine nature, pp. 132-145, Baker, Grand Rapids, MI.

Wright, N.T., 1991, The climax of the covenant, Clark, Edinburgh.

Wright, N.T., 2003, The resurrection of the Son of God, Christian origins and the question of God, vol. 3, Fortress, Augsburg, MN.

Wright, N.T., 2013, Paul and the faithfulness of God, vol. 4, Fortress, MN.

Young, F.M., 1990, 'Understanding Romans in the light of 2 Corinthians', Scottisch Journal of Theology 43, 433-446. https://doi.org/10.1017/S0036930600039417 